RESEARCH PAPER RP651

Part of Bureau of Standards Journal of Research, Vol. 12, February 1934

\title{
A FRACTIONATING COLUMN WITH FRITTED GLASS PLATES ${ }^{1}$
}

\section{By S. T. Schicktanz ${ }^{2}$}

\section{ABSTRACT}

This paper describes a fractionating column with fritted glass plates which has a higher plate efficiency than the usual laboratory bubble-cap column. The efficiency of this type of plate is approximately 98 percent as compared to 87 percent for the bubble-cap plate.

In a previous paper ${ }^{3}$ describing fractionating columns, it was shown that the plate efficiency for the laboratory type of bubble-cap still is only 87 percent. The deficiency of 13 percent is probably due to the large bubbles which are formed on the plates by the large slots in the bubble caps. The efficiency can be increased either by lengthening the time of contact between vapor and liquid or by reducing the size of the bubbles. The time of contact between vapor and liquid can be lengthened only by increasing the height of liquid held on each plate or decreasing the velocity of the vapor and the output of the column. Both alternatives have disadvantages. By increasing the surface of contact between the vapor and liquid through a reduction in the size of the bubbles and by keeping the hold-up of the column and the rate of distillation constant, it is possible to increase the efficiency of the plate.

The Fish-Schurman Corporation ${ }^{4}$ furnished us with fritted glass disks of different porosities which were tested for operative efficiency. The Jena Glass Works of Schott and Genossen constructed a still made entirely of Jena's low coefficient of expansion glass G-20 and made it available to the Bureau. The plates having the finest pores gave the smallest bubbles but developed too great a back pressure. After testing plates of several porosities, those designated by the manufacturer as no. "O" were selected for use in the construction of the experimental still containing five plates.

The design of the column is the same as previously described except that the bubble plate is replaced by a fritted disk, and the liquid overflow, through the side tube, is placed only $1 \mathrm{~cm}$ above the top of the plate. This change keeps the hold-up of the plate equal to that for the bubble cap, although it decreases the height of liquid through which the vapor must pass.

\footnotetext{
1 Financial assistance has been receired from the research fund of the American Petroleum Institute. This work is part of project no. 6; The separation, Identification, and Determination of the Constituents of Petroleum.

2 Research associate representing the American Petroleum Institute at the Bureau of Standards.

3 Laboratory rectifying stills of glass by Johannes $\mathbf{H}$. Bruun and Sylvester T. Schicktanz, B. S. Jour. Research, vol. 7, p. 852, 1931.

230 East Forty-fifth Street, New York, N.Y.
} 
The efficiency tests were made with the usual test mixture containing 50 mole percent each of ethylene chloride (B.P. 83.7 C) and benzene (B.P. 80.2 C). Figure 1 shows the effective separation of the two components when using a reflux ratio of $20: 1$; a rate of collection of the distillate of $1 \mathrm{ml}$ per minute, and keeping the column as well insulated as possible by means of suitable lagging.

The plate efficiencies were determined by the method of McCabe and Thiele. ${ }^{5}$ In this method the distillation is interrupted at a cer-

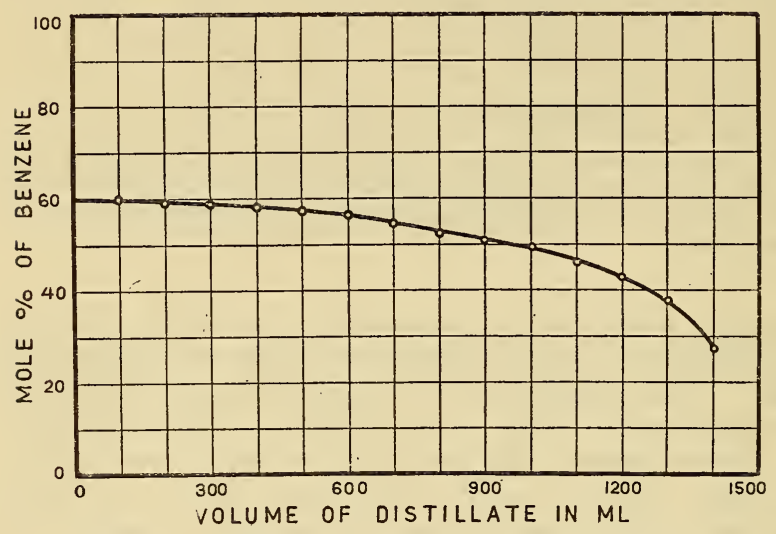

FIGURE 1.-Efficiency curve for a fritted glass plate column containing 5 plates.

Ordinate: Mole percent of benzene in the distillate. Abscissa: Total volume of distillate collected. tain stage and the composition of the distillate and the liquid remaining in the pot are determined. From the reflux ratio and the vapor-liquid diagram of the mixture of these substances, it is possible to obtain an approximate theoretical number of plates which should give the separation shown by the composition of the distillate and pot liquid. This theoretical number of plates, divided by the actual number of plates used and multiplied by 100 , gives the plate efficiency of the still in percentage. Table 1 shows the plate efficiency as determined during the test run.

\section{TABLE 1.-Plate efficiencies of a fritted glass plate column}

\begin{tabular}{|c|c|c|c|c|}
\hline $\begin{array}{c}\text { Percentage } \\
\text { of charge } \\
\text { distilled }\end{array}$ & $\begin{array}{c}\text { Composi- } \\
\text { tion of } \\
\text { fraction } \\
\text { (mole per- } \\
\text { cent ben- } \\
\text { zene) }\end{array}$ & $\begin{array}{c}\text { Composi- } \\
\text { tion of pot } \\
\text { residue } \\
\text { (mole per- } \\
\text { cent ben- } \\
\text { zene) }\end{array}$ & $\begin{array}{c}\text { Theoreti- } \\
\text { cal num- } \\
\text { ber of } \\
\text { plates }\end{array}$ & $\begin{array}{c}\text { Plate eff- } \\
\text { ciency } \\
\text { percent }\end{array}$ \\
\hline & & & & \\
33.3 & 59.9 & 45.3 & 4.94 & $\begin{array}{c}\text { Percent } \\
98.46 \\
53.3\end{array}$ \\
63.3 & 55.1 & 40.5 & 4.91 & 98.3 \\
86.6 & 40.6 & 38.3 & 4.93 & 98.7 \\
\hline
\end{tabular}

These values for the plate efficiency are only approximate and depend to a large extent on the reflux ratio. In a test with an unlagged column, the calculated efficiency was as high as 108 percent, showing that there was a greater reflux ratio throughout the column than was assumed to be present.

This type of still decreases the "H.E.T.P." (height equivalent to a theoretical plate) and is very useful where the height of the room is an essential factor in limiting the effectiveness of a column. 
Because of the small porosity of the plates, the liquid will remain on the plates when the distillation is stopped and will not drain down the column unless the back pressure is decreased too much by condensation of the vapors in the pot and the column.

Although this still is not as efficient as some packed column stills ${ }^{6}$ of the same dimensions, it is more generally useful since corrosive liquids can be readily fractionated without harmful effects to either the liquid or column.

Washington, November 23, 1933.

- See Note on an Improved Chain-Packed Distilling Column, S. T. Schicktanz, B.S., Jour. Research, vol. 11, p. $89,1933$. 